\title{
Saints Christmas Trees Pricing Analysis
}

Michael Pepe, Siena College, USA

Arindam Mandal, Siena College, USA

\begin{abstract}
This teaching case and assignment pertains to various areas of pricing analysis that are essential for business managers. There are numerous pricing components integrated into this case that will enhance students' understanding of various elements that influence pricing decisions. Students will need to analyze and calculate various pricing components that are linked to other economic and marketing concepts. This case is suited for an undergraduate introductory marketing or economics course. Provided at the end of the case are teaching notes for instructors.
\end{abstract}

Keywords: Pricing Analysis; Pricing Objectives; Demand Estimation; Price Elasticity

\section{OVERVIEW OF SAINTS LANDSCAPING}

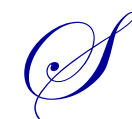

tephen Singer and Wayne Hull, owners and partners of Saints Landscaping, were busy during the Spring months planning for their holiday seasonal business in which Christmas Trees and wreaths are sold. Saints Landscaping has been selling Christmas Trees and wreaths in the Loudonville, New York, area since 2000 and has seen an increase in revenue in each of the past five seasons.

Saints Landscaping relies heavily on the Christmas selling season to supplement the income of the business that is mostly generated during the Spring and Summer months. Saints Christmas Trees is a seasonal business of Saints Landscaping that sells Christmas trees and wreaths for one month preceding Christmas. Orders for Christmas trees need to be placed with growers by July 4 in order to receive the quality and adequate supply desired. The trees for 2011 will be procured from a grower in Canada with the delivered cost fixed at a contractually agreed price of $\$ 20$ for the season. Steve and Wayne make their own wreaths from the trees they purchase.

In planning for the upcoming season, Steve and Wayne need to generate a merchandise plan that will achieve their primary goal of maximizing profits. An integral component in attaining this objective will be decisions regarding the pricing of the Christmas Trees and wreaths.

\section{Loudonville, New York Area}

Saints Landscaping business is located in Loudonville, New York, a few miles north of Albany. There are several competitors in Loudonville that also sell Christmas trees. Home Depot, Lowe's and Wal-Mart are national chain competitors and are located within five miles of Saints Christmas Trees.

\section{QUESTIONS FOR ANALYSIS}

\section{Census Data}

Go to the U.S. Census website and analyze census data for Loudonville, New York, zip code 12211 (www.Census.Gov). What information did you find that would be valuable in formulating pricing decisions? 


\section{Consumer Value}

The owners want to ensure that consumers perceive Saints Christmas Trees as offering a value. Describe what in meant by value and indicate how it is measured. How can the owners increase value without lowering prices?

\section{Profit Business}

Saints Christmas Trees is a for profit business. What are the components of the profit equation that the owners need to manage in order to generate a profit? Analyzing the components of the profit equation, how can the owners increase profits?

\section{Pricing Objectives}

In addition to maximizing profits, identify and discuss other pricing objectives the owners could establish.

\section{Estimating Demand}

- What is the Law of Demand?

- Using the concept of Law of Demand, indicate the potential quantity demanded of Christmas Trees at the various price points provided.

Table 1

\begin{tabular}{|c|c|}
\hline Average Price & Quantity Demanded \\
\hline 30 & 800 \\
\hline 40 & $? ? ?$ \\
\hline 50 & $? ? ?$ \\
\hline
\end{tabular}

- $\quad$ Draw a demand curve portraying your results from the information you provided in the Table 1.

- $\quad$ As business managers, we want to establish brand equity with our product lines and overall business. Using various branding concepts, how can the owners create a positive shift in the demand curve? Why is causing a favorable shift in the demand curve always more beneficial to marketers compared to just changing movement along the demand curve?

\section{Calculating Overall Sales, Profits using Multiple Product Lines}

There will be three price levels for both trees and wreaths based on their various sizes. Each tree has a fixed cost from the growers of $\$ 20$ regardless of size. The owners produce their wreaths from the trees and hire associates for this function. Financial projections for 2011 are based on historical sales information and are provided below:

Table 2

\begin{tabular}{|l|c|c|c|c|c|c|}
\hline Product & Selling Price & Quantity Sold & $\begin{array}{c}\text { Total } \\
\text { Revenue }\end{array}$ & $\begin{array}{c}\text { Unit Total } \\
\text { Cost }\end{array}$ & $\begin{array}{c}\text { Total } \\
\text { Cost }\end{array}$ & $\begin{array}{c}\text { Total } \\
\text { Profit }\end{array}$ \\
\hline Christmas Trees & 30 & 800 & & 20 & & \\
\hline Christmas Trees & 40 & 550 & & 20 & \\
\hline Christmas Trees & 50 & 400 & & 20 & & \\
\hline Christmas Wreaths & 20 & 200 & & 10 & & \\
\hline Christmas Wreaths & 30 & 150 & & 10 & & \\
\hline Christmas Wreaths & 40 & 100 & & 10 & & \\
\hline TOTALS & & & & & \\
\hline
\end{tabular}

- What is the projected Total Revenue?

- What are the projected Total Costs? 
- What is the Gross Profit percentage for Christmas Trees?

- What is the Gross Profit percentage for Christmas wreaths?

- What is the Gross Profit percentage for the total business?

\section{Exchange Rate Impact}

The Christmas trees are procured and imported from a grower in Canada. The following information compares the currency exchange rate between the United States and Canadian dollar on July 1, 2011 and July 1, 2010:

1 U.S. dollar to Canadian dollar (July 1, 2011) - 963832

1 U.S. dollar to Canadian dollar (July 1, 2010) - 1.06

Using your knowledge of exchange rates, why is it important for the owners to be aware of the U.S.Canadian dollar exchange rate? The U.S. dollar has depreciated in value in the past year compared to the Canadian Dollar. What are the implications of the depreciating dollar value on imports into the United States?

\section{Break-even Point}

In order to provide service to consumers and produce the wreaths, Saints Christmas Trees employs four employees for four weeks at a weekly salary of $\$ 250$ each. This amounts to fixed labor expenses of $\$ 4,000$ for the month.

- $\quad$ There is a flat fee of $\$ 20$ paid to the supplier for each Christmas tree purchased. If the average retail price of a Christmas tree is $\$ 37.71$, what is the Break-even Point (BEP)?

\section{Elasticity of Demand}

- $\quad$ Explain price elasticity of demand. Why is this concept important for managers? What is the difference between elastic, inelastic and unitary demand?

- $\quad$ Based on the following scenarios, indicate if Saints Christmas Trees are more likely to be price elastic or inelastic.

- There is an additional competitor selling Christmas trees this year that is located 3 miles from Saints Christmas Trees.

- There is a new technology this year enhancing the quality of artificial trees

- The unemployment rate in the Loudonville area is $8 \%$ this year compared to 5\% last year

\section{Demand-Oriented Pricing Approaches}

- What is the difference between skimming pricing and penetration skimming pricing? Based on the demographic information from the U.S. census, would a skimming or penetration policy by more advantageous and why?

- $\quad$ The owners are considering a bundle pricing offer. Provide an example of a bundle pricing offer that the owners can use.

\section{Business-to-Business Selling (B2B)}

- $\quad$ This year the owners will receive their delivery of Trees on November 25 with a total invoice amount of $\$ 39,750$. The payment terms are $2 / 10$ net 30. Explain what these payments represent.

- $\quad$ The demand for the Canadian business selling to Saints Christmas Trees is an example of derived demand. Explain this concept. 


\section{AUTHOR INFORMATION}

Michael Pepe is an Assistant Professor of Marketing at Siena College in Loudonville, New York. After 19 years as a business professional in the retailing industry, he became a full-time faculty member at Siena in 2009. His research interests include branding, consumer behavior, and pricing strategies. He has presented papers at the College Learning and teaching Conference, Applied Business and research Conference and Marketing Management Association Conference. Michael has published articles in the following academic journals: Journal of Business and Economics Research, Journal of Product and Brand Management, and Journal of Marketing Management. E-mail: mpepe@siena.edu (Corresponding author)

Arindam Mandal is a Visiting Assistant Professor of Economics at Siena College in Loudonville, New York. His primary areas of research are labor economics, macroeconomics and econometrics. He has taught wide range of economics courses including intermediate microeconomics, financial crisis, Principles of Macroeconomics, History of Economic Doctrines, International Finance and Money and Banking. Arindam has published articles in International Journal of Applied Economics and Finance. E-mail: $\underline{\text { amandal @ siena.edu }}$ 


\section{TEACHING NOTES}

\section{Census Data}

- $\quad$ www.census.gov; use zip code 12211

\section{Consumer Value}

- Value is the ratio of perceived benefits to price. It is calculated as follows: Perceived benefits/price

- $\quad$ Students should be aware that value can be increased to consumers by simultaneously increasing product and service benefits while maintaining or decreasing price. All elements of the marketing mix can be used to enhance value to consumers, not just price.

\section{Profit Business}

- $\quad$ Profit $=$ Total Revenue $($ unit price $\mathrm{x}$ quantity sold $)$-Total Cost $($ fixed + variable $)$

- $\quad$ To manage profits, managers need to manage both revenues and costs.

\section{Pricing Objectives}

- $\quad$ Sales, market share, unit volume, social responsibility, survival

\section{Estimating Demand}

Table 1

\begin{tabular}{|c|c|}
\hline Average Price & Quantity Demanded \\
\hline 30 & 800 \\
\hline 40 & $? ? ?$ (needs to be less than 800 ) \\
\hline 50 & $? ? ?$ (needs to be less than the average price of 40 number) \\
\hline
\end{tabular}

- A demand curve is a graph relating the quantity sold and price, which indicates the number of units that will be sold at a given price.

- $\quad$ Brand equity can be enhanced by creating awareness and favorable associations with the business. A shift in the demand curve is favorable since more units will be sold at a particular price level without reducing the price.

\section{Calculating Overall Sales, Profits using Multiple Product Lines}

There will be three price levels for both trees and wreaths based on their various sizes. Each tree has a fixed cost from the growers of $\$ 20$ regardless of size. The owners produce their wreaths from the trees and hire associates for this function. Financial projections for 2012 are based on historical sales information for the entire product assortment (Table 2) based on projections from the owners.

Table 2

\begin{tabular}{|l|c|c|c|c|c|c|}
\hline Product & Selling Price & Quantity Sold & Total Revenue & Unit Total Cost & Total Cost & Total Profit \\
\hline Christmas Trees & 30 & 800 & $\mathbf{2 4 , 0 0 0}$ & 20 & $\mathbf{1 6 , 0 0 0}$ & $\mathbf{8 , 0 0 0}$ \\
\hline Christmas Trees & 40 & 550 & $\mathbf{2 2 , 0 0 0}$ & 20 & $\mathbf{1 1 , 0 0 0}$ & $\mathbf{1 1 , 0 0 0}$ \\
\hline Christmas Trees & 50 & 400 & $\mathbf{2 0 , 0 0 0}$ & 20 & $\mathbf{8 , 0 0 0}$ & $\mathbf{1 2 , 0 0 0}$ \\
\hline Christmas Wreaths & 20 & 200 & $\mathbf{4 , 0 0 0}$ & 10 & $\mathbf{2 , 0 0 0}$ & $\mathbf{2 , 0 0 0}$ \\
\hline Christmas Wreaths & 30 & 150 & $\mathbf{4 , 5 0 0}$ & 10 & $\mathbf{1 , 5 0 0}$ & $\mathbf{3 , 0 0 0}$ \\
\hline Christmas Wreaths & 40 & 100 & $\mathbf{4 , 0 0 0}$ & 10 & $\mathbf{1 , 0 0 0}$ & $\mathbf{3 , 0 0 0}$ \\
\hline TOTALS & & $\mathbf{7 8 , 5 0 0}$ & & $\mathbf{3 9 , 5 0 0}$ & $\mathbf{3 9 , 0 0 0}$ \\
\hline
\end{tabular}


- What is the projected Total Revenue? $\quad \mathbf{8 7 8 , 5 0 0}$

- What are the Total Costs? $\mathbf{\$ 3 9 , 5 0 0}$

- What is the Gross Profit percentage for Christmas Trees? $46.96 \%(31,000 / 66,000)$

- What is the Gross Profit percentage for Christmas wreaths? 64\% $(8,000 / \mathbf{1 2 , 5 0 0})$

- What is the Gross Profit percentage for the total business? 49.68\% (39,000/78,500)

\section{Exchange Rate Impact}

- $\quad$ Currency exchange rates are the price of one country's currency expressed in terms of another country's currency. Exchange rates should be monitored closely by international companies as they impact cost of imported and exported goods.

- In the scenario provided in the case study, a weaker U.S. dollar - in relation to the Canadian dollar - makes imports from Canada more expensive.

\section{Break-even Point}

- $\quad$ The Break-even point (BEP) is the quantity at which total revenue and total cost are equal. Profit comes from all units sold beyond the BEP. The BEP, in this example, is $226(4000 /(37.71-20)$.

\section{9. $\quad$ Elasticity of Demand}

- $\quad$ Price elasticity of demand is the percentage change in quantity demanded relative to a percentage change in price. This concept is important to managers because of its relationship to total revenue.

- $\quad$ Elastic demand occurs when a $1 \%$ decrease in price results in more than a $1 \%$ increase in quantity demanded, thereby increasing sales revenue. Inelastic demand occurs when a $1 \%$ decrease in price results in less than a $1 \%$ increase in quantity demanded, thereby decreasing sales revenue. Unitary demand occurs when the percentage change in price is the same as the percentage change in quantity demanded.

- $\quad$ Based on the following scenarios, indicate if Saints Christmas trees are more likely to be price elastic or inelastic.

- There is an additional competitor selling Christmas trees this year that is located three miles from Saints Christmas Trees. ELASTIC

- There is a new technology this year enhancing the quality of artificial trees. ELASTIC

- The unemployment rate in the Loudonville area is $8 \%$ this year compared to 5\% last year. ELASTIC

\section{Demand-oriented Pricing Approaches}

- $\quad$ Skimming pricing involves setting the highest initial price that the customers really desiring the product will pay. Penetration pricing involves setting a low price. Based on the demographic information from the U.S. census for Loudonville, New York, a price skimming policy should be implemented based on the affluent consumer base.

- $\quad$ An example of a bundle pricing offer that the owners can use would be a reduction in price if a wreath is purchased along with a tree.

\section{Business-to-Business Selling (B2B)}

- $\quad$ This represents a cash discount. If the owners pay within 10 days of receipt of the tress, the amount owed will be $\$ 38,955$. The total amount of $\$ 39,750$ is due within 30 days.

- Derived demand indicates that the demand for business goods is derived from demand for consumer goods. The owners will only procure the amount of trees that consumers will demand. 